\title{
Effect of Edible Packaging Film Treated with Essential Oil of Oregano in Extending the Shelf Life of Paneer
}

\author{
Saurabh Karunamay, Shekhar R. Badhe*, Vivek Shulka, Poonam A. Pawar \\ Department of Livestock Products Technology, Mumbai Veterinary College, \\ MAFSU, Mumbai, Maharashtra, India \\ *Corresponding author
}

\section{A B S T R A C T}

\begin{tabular}{l} 
Ke y w or d s \\
Paneer, Oregano \\
essential oil, CMC, \\
Starch, Shelf-life \\
\hline Article Info \\
\hline $\begin{array}{l}\text { Accepted: } \\
\text { 18 May } 2020 \\
\text { Available Online: } \\
\text { 10 June } 2020\end{array}$ \\
\hline
\end{tabular}

The present study was conducted to evaluate the shelf- life of paneer wrapped with oregano essential oil treated starch and carboxymethyl cellulose (CMC) based edible packaging film. The edible film was prepared by adding starch $(5 \mathrm{~g})$, carboxymethyl cellulose (15\% W/W starch) in distilled water $(100 \mathrm{~mL})$ and glycerol $(40 \mathrm{ml} / 100 \mathrm{~g}$ starch). Physicochemical, microbiological and sensory properties at $\left(4 \pm 1^{\circ} \mathrm{C}\right)$ till spoilage was evaluated for paneer samples. Control sample was unacceptable after $5^{\text {th }}$ day of storage for sensory evaluation and found microbiologically unfit on $9^{\text {th }}$ day of storage. The paneer packed in edible film treated with $0.5 \%$ oregano essential oil was found bland on $10^{\text {th }}$ day of sensory evaluation but found microbiologically fine at $12^{\text {th }}$ day of storage. The results revealed that paneer packed in edible film treated with oregano essential oil was found microbiologically safe for at least 12 days as compared to 5-6 days for control sample at $4 \pm 1^{\circ} \mathrm{C}$.

\section{Introduction}

Paneer refers as a dairy product obtained from the cow or buffalo milk or a combination there of by coagulation with sour milk, lactic acid or citric acid. It should not contain more than 70.0 per cent moisture and milk fat less than 50.0 per cent of the dry matter (FSSAI, 2011). Like other dairy products, paneer also shows a shelf- life of 5-6 days under refrigeration, though its freshness is lost within 3 days (Bhattacharya et al., 1971). Retort packaging, vacuum packaging and many more modern packaging methods have been developed to increase the shelf life of paneer. The packaging materials mostly used in the food industries are non- biodegradable and the problems generated by nondegradable or plastic waste are of great concern. 
In order to overcome the issue, the research has been carried out to use natural compounds for the preservation of paneer. Thus, an ecofriendly, biodegradable and oregano essential oil treated starch and carboxylmethyl cellulose based edible packaging film was developed for this purpose. Oregano essential oil (OEO) is obtained from Oregano plant (Origanum vulgare) and has carvacrol and thymolas major active compounds. These compounds possess high antimicrobial activity and excellent antioxidant properties against a wide range of spoilage and pathogenic microorganisms. Generally recognized as safe (GRAS) status of oregano essential oil by FDA gave researcher a pave the way to incorporation this oil in starch and carboxymethyl cellulose based edible film for extensive studies. The objective of present research work was to study the effectiveness of starch and carboxymethyl cellulose base edible film, incorporated with oregano essential oil to extend the shelf life of paneer stored at refrigeration temperature $\left(4 \pm 1 \mathrm{C}^{\circ}\right)$.

\section{Materials and Methods}

\section{Preparation of paneer}

Freshly dawn buffalo milk was procured from cattle and buffalo farm of Mumbai Veterinary College and used throughout the experiments. The fat percentage and S.N.F was standardized to $6 \%$ and $9 \%$ respectively for most favorable product characteristics. Strength of $1 \%$ citric acid was used to coagulate the milk for preparation of paneer. In present study, paneer samples were prepared by the method suggested by Kumar et al., (2014) with slight modifications.

\section{Preparation of edible film treated with essential oil}

The suspension of edible film was prepared by adding starch (5 g), carboxylmethyl cellulose $(15 \%$ W/W starch) in $100 \mathrm{~mL}$ distilled water and added glycerol $(40 \mathrm{ml} / 100$ g starch). The Suspension was agitated by magnetic stirrer at $500 \mathrm{rpm}$ for $30 \mathrm{~min}$ in water bath at $90{ }^{\circ} \mathrm{C}$. After that the suspension was cooled for 20 minutes and $0.5 \%$ oregano essential oil was added as per the volume of the solution. The desired concentration of oregano essential oil was determined by Minimum inhibition concentration. The suspension was then dried at $60{ }^{\circ} \mathrm{C}$ to obtain the film (Ghanbarzadeh et al., 2011).

\section{Packaging and storage of paneer}

Control (C) and treatment (T) samples of 20 grams each was prepared. Control sample contained paneer packed in LDPE bag and kept at $4 \pm 1^{\circ} \mathrm{C}$. Treatment (T) sample contained paneer wrapped in edible packaging film treated with $0.5 \%$ oregano essential oil and then packed in LDPE bag and stored at $4 \pm 1{ }^{\circ} \mathrm{C}$. Before analysis the control and treatment paneer samples were kept at $15^{\circ} \mathrm{C}$ for 1 hour.

\section{Physico-chemical and microbiological analysis}

Control and treated paneer sample were analyzed for $\mathrm{pH}$ as determined by the method of Trout et al., (1992). Digital pH meter (Model-HI 99163, HANNA) was used to record the $\mathrm{pH}$ of the suspension. TBA value was determined by the procedure described by Witte et al., (1970) with little modification and the absorbance (A) was measured at $530 \mathrm{~nm}$ in a spectrophotometer (Model no. EQ 820 with wavelength range of $350-950 \mathrm{~nm}$, INDIA). The procedure of tyrosine value was determined as per described by Strange et al., (1977) with slight modifications. The absorbance (A) was measured at $730 \mathrm{~nm}$ using Spectrophotometer. Tyrosine value was calculated as milligram tyrosine per 100 gram of sample by referring to a standard graph, as 
per described by Pearson (1968). Titratable acidity of the control and treated sample were determined as per AOAC (1995). Total plate count, psychrophilic count, yeast and mold count and coliform count of paneer samples were estimated by the standard methods of APHA (1992).

\section{Sensory evaluation of paneer}

The sensory evaluations of fresh and stored paneer samples were conducted by semitrained panel of 6 judges and it was repeated at the interval of 5 days. The samples were judge for various sensory attributes using nine point Hedonic scales as described by (Keeton, 1983).

\section{Statistical analysis}

The data recorded in triplicate $(n=3)$ during the experiment were analyzed by analysis of variance (ANOVA) using complete randomized block design (CRBD) following standard procedure as per (Snedecor and Cochran, 1989).

\section{Results and Discussion}

\section{Physico-chemical parameters}

Physico-chemical parameters of paneer samples like $\mathrm{pH}$, tyrosine, TBA value and titratable acidity were analyzed at $0^{\text {th }}, 3^{\text {rd }}, 6^{\text {th }}$, $9^{\text {th }}, 12^{\text {th }}$ and $15^{\text {th }}$ day of storage (Table 1$)$. The initial $\mathrm{pH}$ values were non-significant till $9^{\text {th }}$ day for control and treatment. Significant $(\mathrm{p}<0.05)$ difference among control and treatment was observed on day $12^{\text {th }}$ and day $15^{\text {th }}$ of storage.

Compounds like carvacrol and thymol in oregano essential oil helps to maintain the $\mathrm{pH}$ of paneer during entire storage. Results were in accordance with Rai et al., (2008) and Makhal et al., (2014) for thymol added cottage cheese. The average tyrosine values for control and treatment shows nonsignificant difference on $0^{\text {th }}$ day. A significant $(\mathrm{p}<0.05)$ difference was observes between $3^{\text {rd }}$ day to $15^{\text {th }}$ day of storage. Rai et al., (2008) analyzed chemical quality of paneer at $7 \pm 1^{\circ} \mathrm{C}$ and showed a similar finding.

Singh and Immanuel (2014) also reported similar result of tyrosine value in paneer added with fruits peels. At the end of storage, the tyrosine value for control was found to be much higher as compared to treatment, which indicates less proteolysis in treated paneer samples.

The average TBA values for control and treatment shows a non-significant difference on 0 day. But a significant $(\mathrm{p}<0.05)$ difference was noticed for control and treatment from $3^{\text {rd }}$ day to $15^{\text {th }}$ day of storage. The value of TBA in paneer sample treated with oregano essential oil was considerably lower than that of the control, indicating that the oregano essential oil protected paneer against lipid oxidation. The results were in agreement with the reports of Shan et al., (2011) for cheese added with oregano herbs extract and Chauhan et al., (2015) for paneer.

Initial acidity of the control paneer samples were $0.29 \%$. Slow and gradual increase in acidity was developed during storage. The average titratable acidity values for control and treatment showed a non-significant difference on $0^{\text {th }}$ day. But a significant $(p<0.05)$ difference was noticed in control and treatment from $3^{\text {rd }}$ day to $15^{\text {th }}$ day of storage. Incorporation of oregano essential oil into edible film of paneer delayed the acid development during storage, possibly because of its antimicrobial activity against the spoilage causing microorganisms. The results were in agreement with the reports of and Makhal et al., (2014) for paneer and Yadav et al., (2019) for thyme herbs added paneer. 


\section{Microbiological parameters}

Control and treatment paneer samples were subjected to microbiological count subsequently at $0^{\text {th }}, 3^{\text {rd }}, 6^{\text {th }}, 9^{\text {th }}, 12^{\text {th }}$ and $15^{\text {th }}$ day of storage (Table 2).Total plate count (TPC $\log _{10} \mathrm{cfu} / \mathrm{g}$ ) for control and treatment was nil on $0^{\text {th }}$ day. A significant difference $(p<0.05)$ was observed in control and treatment from $3^{\text {th }}$ day to $15^{\text {th }}$ day of storage. On $9^{\text {th }}$ day of storage control was on unacceptable limit whereas treatment was under acceptable limit till $12^{\text {th }}$ day of storage. The reduction in total plate count was perhaps on account of the bactericidal effect of oregano essential oil. A similar result of total plate count for oregano essential oil treated cheese was reported by Olmedo et al., (2013) and Rani et al., (2014) for masala paneer.

Psychrophilic count of control sample was nil on $0^{\text {th }}$ day and $3^{\text {rd }}$ day whereas, for treatment sample psychrophilic count was nil on $0^{\text {th }}, 3^{\text {rd }}$ and $6^{\text {th }}$ day of storage. On $6^{\text {th }}$ day control showed the growth with count of $4.63 \pm 0.01$ $\log \mathrm{cfu} / \mathrm{g}$. A significant difference $(\mathrm{p}<0.05)$ was observed by control and treatment from $9^{\text {th }}$ day to $12^{\text {th }}$ day of storage. Gradual increase in psychrophilic count was observed in control than treatment upon $15^{\text {th }}$ day of storage. Numerous studies show that oregano essentials oils have strong bactericidal effect Lambert et al., (2001). Similar result was also reported by Makhal et al., (2014) and Artiga et al., (2017) that stated the lower growth of psychrotrophs in cottage cheese samples added with essential oils is due to its strong antimicrobial action.

The average yeast and mold count for control and treatment were nil on $0^{\text {th }}$ day whereas on $3^{\text {rd }}$ day, only control sample showed the growth (Fig.1).A significant $(\mathrm{p}<0.05)$ difference was noticed in control and treatment from $6^{\text {th }}$ day to $15^{\text {th }}$ day of storage. Owing to the antifungal action (Munhuweyi et al., 2018), the oregano essential oil was observed to exhibit a significant inhibitory effect against growth of yeast and molds during the entire storage period. The results of yeast and mold count were in agreement with Buch et al., (2014) for paneer and Artiga et al., (2017) for oregano essential oil coated cheese. The coliform count for both control and treatment samples were negative during entire period of storage. It shows that the sample was not contaminated by any coliform bacteria from any route.

\section{Sensory evaluation}

Control and treatment paneer samples were subjected to sensory evaluation for the parameters like appearance, juiciness, flavor, texture and overall acceptability subsequently at 5 days interval (Table. 3). There was slight decrease in appearance of stored control (Fig. 2A) and treatment (Fig. 2B) paneer samples with the increase in storage period. Yellowish tint appearance was observed at the end of storage period. The appearance of control and treated samples decreased significantly $(p<0.05)$ throughout the storage. Juiciness of control paneer sample showed significant $(\mathrm{p}<0.05)$ decreased from 8.46 to 7.54 in 5 days. Juiciness of treatment paneer sample showed a significant $(\mathrm{p}<0.05)$ decrease of 8.35 to 6.49 from initial day to $10^{\text {th }}$ day of storage.

There was a significant $(\mathrm{p}<0.05)$ decrease in flavour of control paneer sample from 7.95 to 7.32 in 5 days. The flavor of treatment paneer sample also showed a significant $(\mathrm{p}<0.05)$ decrease of 8.72 to 7.68 from $0^{\text {th }}$ day to $10^{\text {th }}$ day of storage. There was also a gradual and significant $(\mathrm{p}<0.05)$ decrease in texture score of control paneer sample from 8.98 to 8.12 in 5 days. The treatment paneer sample also showed a significant $(\mathrm{p}<0.05)$ decreased texture score of 8.95 to 7.14 from initial day to $10^{\text {th }}$ day of storage. 
Table.1 Physico-chemical parameters of control and treatment during storage period

\begin{tabular}{|c|c|c|c|c|c|c|c|c|}
\hline Parameters & \multicolumn{2}{|c|}{ pH } & \multicolumn{2}{|c|}{ Tyrosine } & \multicolumn{2}{|c|}{ TBA } & \multicolumn{2}{|c|}{ Titratable Acidity } \\
\hline Day & $\mathbf{C}$ & $\mathbf{T}$ & $\mathbf{C}$ & $\mathbf{T}$ & $\mathbf{C}$ & $\mathbf{T}$ & $\mathbf{C}$ & $\mathbf{T}$ \\
\hline $0^{\text {th }}$ Day & ${ }^{5} 5.85 \pm 0.03^{A}$ & ${ }_{a} 5.87 \pm 0.02^{A}$ & ${ }_{\mathrm{a}} 12.52 \pm 0.06^{\mathrm{A}}$ & ${ }_{\mathrm{a}} 12.45 \pm 0.01^{\mathrm{A}}$ & ${ }_{a} 0.22 \pm 0.01^{\mathrm{A}}$ & ${ }_{\mathrm{a}} 0.23 \pm 0.02^{\mathrm{A}}$ & ${ }_{\mathrm{a}} 0.29 \pm 0.01^{\mathrm{A}}$ & ${ }_{\mathrm{a}} 0.30 \pm 0.01^{\mathrm{A}}$ \\
\hline $3^{\text {rd }}$ Day & ${ }^{5} 5.83 \pm 0.04^{\mathrm{A}}$ & ${ }_{a} 5.77 \pm 0.02^{A}$ & $\mathrm{~b} 15.38 \pm 0.05^{\mathrm{B}}$ & $\mathrm{b} 15.84 \pm 0.04^{\mathrm{A}}$ & $\mathrm{b} 0.36 \pm 0.01^{\mathrm{B}}$ & $\mathrm{b} 0.26 \pm 0.02^{\mathrm{A}}$ & ${ }_{b} 0.43 \pm 0.01^{B}$ & $\mathrm{~b} 0.40 \pm 0.02^{\mathrm{A}}$ \\
\hline $6^{\text {th }}$ Day & ${ }_{\mathrm{a}} 5.77 \pm 0.02^{\mathrm{A}}$ & ${ }^{2} 5.75 \pm 0.03^{A}$ & ${ }_{\mathrm{c}} 19.78 \pm 0.05^{\mathrm{B}}$ & $\mathrm{c} 17.08 \pm 0.01^{\mathrm{A}}$ & ${ }_{c} 0.48 \pm 0.01^{B}$ & $c_{0} 0.32 \pm 0.06^{\mathrm{A}}$ & ${ }_{c} 0.55 \pm 0.02^{\mathrm{B}}$ & $c 0.49 \pm 0.02^{\mathrm{A}}$ \\
\hline $9^{\text {th }}$ Day & ${ }^{2} 5.76 \pm 0.03^{A}$ & ${ }_{a} 5.69 \pm 0.01^{A}$ & $\mathrm{~d}^{3} 31.14 \pm 0.02^{\mathrm{B}}$ & ${ }_{d} 25.16 \pm 0.02^{A}$ & ${ }_{d} 0.68 \pm 0.02^{B}$ & ${ }_{d} 0.55 \pm 0.02^{A}$ & ${ }_{d} 0.62 \pm 0.02^{B}$ & ${ }_{d} 0.53 \pm 0.01^{A}$ \\
\hline $12^{\text {th }}$ Day & $\mathrm{b}^{5.56} \pm 0.01^{\mathrm{B}}$ & ${ }_{a}^{5.71 \pm 0.04} 4^{\mathrm{A}}$ & $e^{40.53 \pm 0.03^{B}}$ & $\mathrm{e}^{30.20 \pm 0.05^{\mathrm{A}}}$ & $e^{0.93 \pm 0.02^{B}}$ & $\mathrm{e}^{0.74 \pm 0.03^{\mathrm{A}}}$ & $e^{0.74 \pm 0.01^{B}}$ & $e^{0.59 \pm 0.01} 1^{A}$ \\
\hline $15^{\text {th }}$ Day & ${ }_{b} 5.55 \pm 0.03^{B}$ & ${ }_{b} 5.69 \pm 0.03^{A}$ & $47.54 \pm 0.25^{B}$ & $\mathrm{f}^{3} 3.65 \pm 0.22^{\mathrm{A}}$ & ${ }_{\mathrm{f}} 1.16 \pm 0.06^{\mathrm{B}}$ & $0.86 \pm 0.08^{A}$ & $0.79 \pm 0.02^{B}$ & $\mathrm{f} 0.71 \pm 0.01^{\mathrm{A}}$ \\
\hline
\end{tabular}

*Note: Row wise mean bearing subscript and column wise mean bearing superscript indicates significant and non-significant difference at $(\mathrm{p}<0.05 \%)$

Table.2 Microbiological count (log cfu/g) of control and treatment of paneer during storage period

\begin{tabular}{|c|c|c|c|c|c|c|}
\hline Parameters & \multicolumn{2}{|c|}{ Total Plate Count } & \multicolumn{2}{|c|}{ Psychrophilic count } & \multicolumn{2}{|c|}{ Yeast and Mold Count } \\
\hline Day & $\mathbf{C}$ & $\mathbf{T}$ & $\mathbf{C}$ & $\mathbf{T}$ & $\mathbf{C}$ & $\mathbf{T}$ \\
\hline $0^{\text {th }}$ Day & NIL & NIL & NIL & NIL & NIL & NIL \\
\hline $3^{\text {rd }}$ Day & ${ }_{\mathrm{a}} 1.97 \pm 0.09^{\mathrm{B}}$ & ${ }_{\mathrm{a}} 1.20 \pm 0.12^{\mathrm{A}}$ & NIL & NIL & $2.53 \pm 0.18$ & NIL \\
\hline $6^{\text {th }}$ Day & $\mathrm{b} 3.30 \pm 0.15^{\mathrm{B}}$ & $\mathrm{b} 2.20 \pm 0.12^{\mathrm{A}}$ & ${ }_{a} 4.63 \pm 0.01^{\mathrm{A}}$ & NIL & b $3.28 \pm 0.17^{\mathrm{B}}$ & $\mathrm{a} 2.53 \pm 0.07^{\mathrm{A}}$ \\
\hline $9^{\text {th }}$ Day & $c 5.0 \pm 0.10^{\mathrm{B}}$ & c $3.40 \pm 0.12^{\mathrm{A}}$ & ${ }_{b} 5.03 \pm 0.01^{B}$ & $\mathrm{a} 3.57 \pm 0.02^{\mathrm{A}}$ & ${ }_{b} 3.37 \pm 0.01^{B}$ & $\mathrm{~b} 3.06 \pm 0.01^{\mathrm{A}}$ \\
\hline $12^{\text {th }}$ Day & ${ }_{\mathrm{d}} 5.80 \pm 0.12^{\mathrm{B}}$ & ${ }_{d} 4.57 \pm 0.12^{A}$ & ${ }_{a} 5.18 \pm 0.00^{B}$ & ${ }^{6} 4.81 \pm 0.02^{A}$ & ${ }_{\mathrm{b}} 3.45 \pm 0.02^{\mathrm{B}}$ & $\mathrm{b} 3.18 \pm 0.01^{\mathrm{A}}$ \\
\hline $15^{\text {th }}$ Day & e $6.77 \pm 0.03^{B}$ & $e^{5.37 \pm 0.09^{A}}$ & ${ }_{a} 5.20 \pm 0.01^{B}$ & ${ }^{5} 5.00 \pm 0.01^{\mathrm{A}}$ & ${ }_{b} 3.52 \pm 0.01^{B}$ & c $3.31 \pm 0.02^{\mathrm{A}}$ \\
\hline
\end{tabular}

*Note: Row wise mean bearing subscript and column wise mean bearing superscript indicates significant and non-significant difference at $(\mathrm{p}<0.05 \%)$. 
Table.3 Sensory scores of control and treatment during storage period

\begin{tabular}{|c|c|c|c|}
\hline Day & $0^{\text {th }}$ Day & $5^{\text {th }}$ Day & $10^{\text {th }}$ Day \\
\hline \multicolumn{4}{|c|}{ Sensory Evaluation } \\
\hline \multicolumn{4}{|l|}{ Appearance } \\
\hline Control & $8.98 \pm 0.02^{\mathrm{A}}$ & $\mathrm{b} 7.97 \pm 0.12^{\mathrm{A}}$ & $\mathrm{NC}$ \\
\hline Treatment & ${ }_{a} 8.97 \pm 0.02^{B}$ & $\mathrm{~b} 8.60 \pm 0.12^{\mathrm{B}}$ & $\mathrm{a} 7.52 \pm 0.10^{\mathrm{B}}$ \\
\hline \multicolumn{4}{|l|}{ Juiciness } \\
\hline Control & $\mathrm{a} 8.46 \pm 0.14^{\mathrm{A}}$ & $\mathrm{b} 7.54 \pm 0.18^{\mathrm{A}}$ & $\mathrm{NC}$ \\
\hline Treatment & ${ }_{a} 8.35 \pm 0.10^{B}$ & $\mathrm{~b} 7.76 \pm 0.15^{\mathrm{B}}$ & $6.49 \pm 0.14^{B}$ \\
\hline \multicolumn{4}{|l|}{ Flavour } \\
\hline Control & a $7.95 \pm 0.18^{A}$ & $\mathrm{~b} 7.32 \pm 0.16^{\mathrm{A}}$ & $\mathrm{NC}$ \\
\hline Treatment & ${ }_{a} 8.72 \pm 0.16^{B}$ & 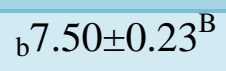 & a $7.68 \pm 0.24^{B}$ \\
\hline \multicolumn{4}{|l|}{ Texture } \\
\hline Control & $8.98 \pm 0.02^{\mathrm{A}}$ & ${ }_{b} 8.12 \pm 0.18^{\mathrm{A}}$ & $\mathrm{NC}$ \\
\hline Treatment & ${ }_{a} 8.95 \pm 0.03^{B}$ & ${ }_{b} 8.36 \pm 0.16^{\mathrm{B}}$ & $\mathrm{a} 7.14 \pm 0.15^{\mathrm{B}}$ \\
\hline \multicolumn{4}{|c|}{ Overall Acceptability } \\
\hline Control & $\mathrm{a} 8.59 \pm 0.04^{\mathrm{A}}$ & $\mathrm{b} 7.74 \pm 0.08^{\mathrm{A}}$ & $\mathrm{NC}$ \\
\hline Treatment & ${ }_{a} 8.75 \pm 0.06^{B}$ & $b 8.05 \pm 0.08^{B}$ & a $7.20 \pm 0.08^{\mathrm{B}}$ \\
\hline
\end{tabular}

*Note: Row wise mean bearing subscript and column wise mean bearing superscript indicates significant and nonsignificant difference at $(\mathrm{p}<0.05 \%) . \mathrm{NC}=$ Not conducted

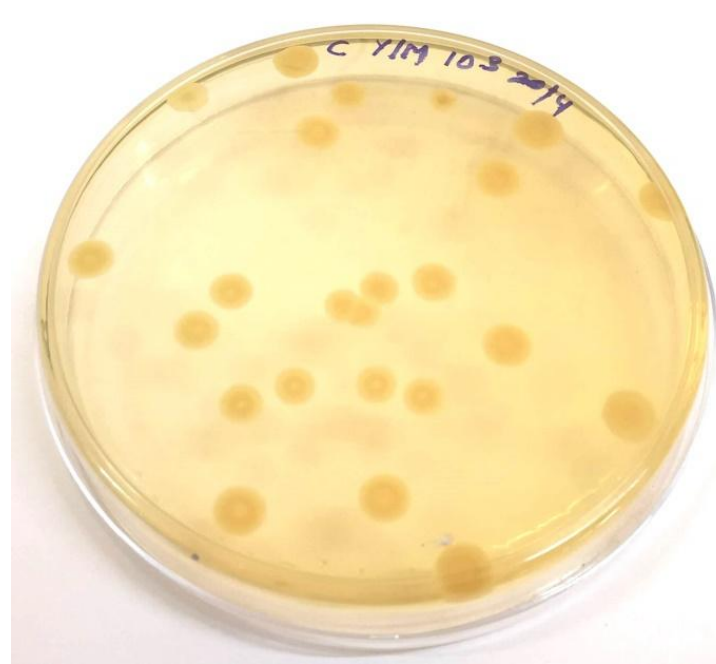

(A)

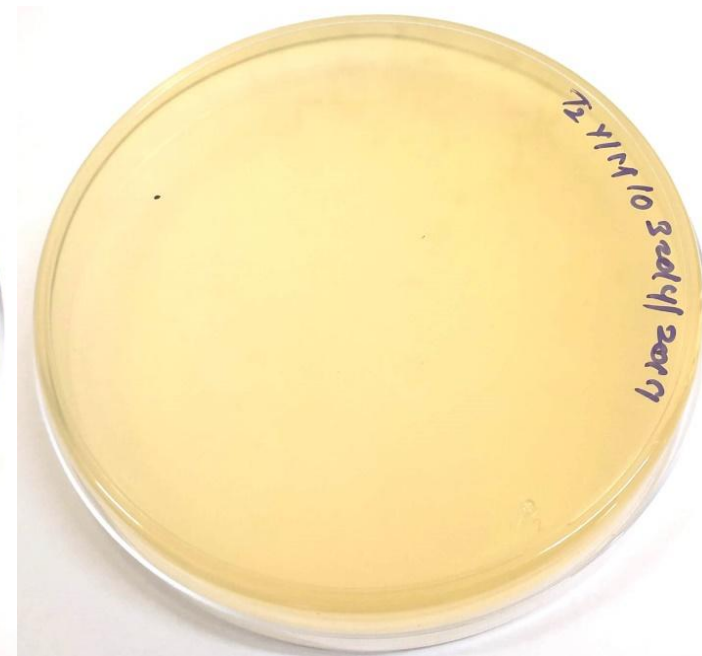

(B)

Fig.1 (A) Shows yeast and mould growth on $3^{\text {rd }}$ day for control sample.

(B) Shows no growth of yeast and mould on $3^{\text {rd }}$ day of storage for paneer sample wrapped in oregano oil treated edible film 


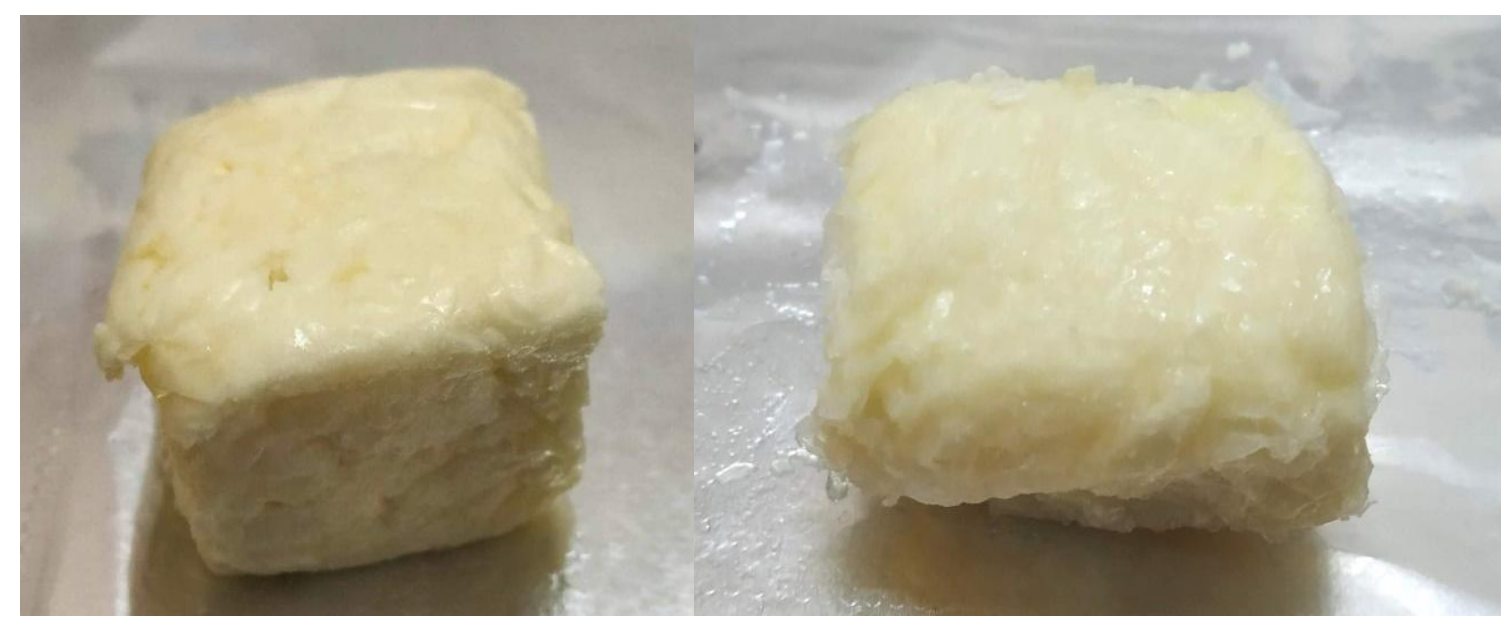

(A)

(B)

Fig.2 (A) Shows control paneer sample on $6^{\text {th }}$ day (B) Shows treatment paneer sample wrapped in oregano essential oil treated edible film on $9^{\text {th }}$ day of storage

There was significantly $(\mathrm{p}<0.05)$ decrease in overall acceptability of both control and treatment with the increase in storage period. The overall acceptability of both control and treatment samples were within desirable range, but slightly poorer for control samples as compared to treated sample. Sensory evaluation of control sample was not conducted after $5^{\text {th }}$ day because it was found microbiologically unfit on $9^{\text {th }}$ day of storage.

For treatment sample, overall acceptability was unfavorable on $10^{\text {th }}$ day of evaluation. The scores for appearance, flavor, juiciness and texture were affected by the increase acidity and decreasing moisture content, similar finding was reported by Kumar et al., (2008). Ahmed \& Bajwa (2019) also stated the similar result as degradation of reducing sugar leads to $\mathrm{pH}$ drop and alteration of sensory qualities in paneer.

\section{Acknowledgement}

Authors are highly thankful to Department of Livestock Products Technology, Mumbai Veterinary College, MAFSU, Mumbai, Maharashtra for providing research oriented environment for successful completion of this work.

\section{References}

Ahmed, A., \& U. Bajwa. 2019. Composition, texture and microstructure appraisal of paneer coagulated with sour fruit juices. Journal of Food Science and Technology, 56(1), 253-261.

A.O.A.C. (1995) Official method of analysis.15Th Edition, Association of Analytical Chemists, Washington D.C; USA.

Artiga-Artigas, M., Acevedo-Fani, A., \& Martín-Belloso, O. 2017. Improving the shelf life of low-fat cut cheese using nanoemulsion-based edible coatings containing oregano essential oil and mandarin fiber. Food Control, 76, 1-12.

American Public Health Association. 1992. Compendium of Methods for the Microbiological Examination of Foods 3rd Edition APHA Inc. Washington DC. Retrieved Dec, 27, 2013.

Bhattacharya, D.C., Mathur. O. N., Srinivasan.M. R., Samlik. O. 1971.Studies on the Methods of Production and Shelf life of Paneer (Cooking Type of Acid Coagulated cottage cheese). Journal of Food Science Technology, 1971; 8(5):117120. 
Buch, S., Pinto.S., \&Aparnathi, K. D. 2014.Evaluation of efficacy of turmeric as a preservative in paneer.Journal of Food Science and Technology, 51(11), 3226-3234.

Chauhan, O. P., Kumar. S., Nagraj, R., Narasimhamurthy, R., \& Raju, P. S. 2015.Effect of high pressure processing on yield, quality and storage stability of peanut paneer.International Journal of Food Science \& Technology, 50(6), 1515-1521.

FSSAI.Food Products Standards and Food Additives.Food Safety and Standards Regulations, 7th edition. International law book company publication, Delhi, India, 2011, 270.

Ghanbarzadeh, B., H. Almasi, H., \&Entezami, A. A. 2011.Improving the barrier and mechanical properties of corn starchbased edible films: Effect of citric acid and carboxymethyl cellulose.Industrial Crops and products, 33(1), 229-235.

Keeton, J. T. 1983. Effect of fat and $\mathrm{NaCl} /$ phosphate level on the chemical and sensory properties of pork patties.Journal of Food Science. 48: pp 787-885.

Kumar, S., Rai, D. C., \&Verma, D. N. 2008. Effect of different levels of lactic acid on the physico-chemical and sensory attributes of buffalo milk paneer. Indian Journal of Animal Research, 42(3), 205-208.

Kumar, S., Rai, D. C., Niranjan. K., \& Bhat, Z. F. 2014. Paneer-An Indian soft cheese variant: a review. Journal of Food Science and Technology, 51(5), 821-831.

Lambert, R. J. W., Skandamis, P. N.,Coote, P. J., \&Nychas, G. J. 2001. A study of the minimum inhibitory concentration and mode of action of oregano essential oil, thymol and carvacrol. Journal of applied microbiology, 91(3), 453-462.

Makhal, S., Kanawjia, S. K., \&Giri, A.
2014.Effectiveness of thymol in extending keeping quality of cottage cheese. Journal of Food Science and Technology, 51(9), 2022-2029.

Munhuweyi, K., Caleb, O. J., van Reenen, A. J., \&Opara, U. L. 2018.Physical and antifungal properties of $\beta$-cyclodextrin microcapsules and nanofibre films containing cinnamon and oregano essential oils.LWT - Food Science and Technology,87, 413-422.

Olmedo, R. H., Nepote, V., \& Grosso, N. R. 2013. Preservation of sensory and chemical properties in flavoured cheese prepared with cream cheese base using oregano and rosemary essential oils. LWT-Food Science and Technology, 53(2), 409-417.

Pearson, D. (1968). Application of chemical methods for the assessment of beef quality. II methods related to protein break down. Journal of the Science of Food and Agriculture 19 (7): 366-369.

Rai, S., Goyal, G. K. and Rai, G. K. 2008.Effect of modified atmosphere packaging and storage on the chemical quality of paneer.Journal of dairying, foods \& home sciences. 27:33-37.

Rani, M., Dabur, R. S., Garg, S. R., \&Jadhav, V. 2014. Preparation, storage and microbiological quality of ready-toserve low cholesterol masala paneer. Veterinary World, 7(6), 443-447.

Shan, B., Cai, Y. Z., Brooks, J. D., andCorke, H. 2011. Potential application of spice and herb extracts as natural preservatives in cheese. Journal of medicinal food, 14(3), 284-290.

Singh, S., \& Immanuel, G. 2014.Extraction of antioxidants from fruit peels and its utilization in paneer. Journal of Food Processing \& Technology, 5(7), 1.

Snedecor, G. W., and Cochran, W. J. 1989.Statistical Methods, 8thEdn; lowa State University press, Amer. Lowa, USA. 
Strange, E. D., Benedict, R. C., Smith, J.C., and Swift, L. E. 1977.Evaluation of rapid tests for monitoring alterations in meat quality storage. I. Intact Meat. Journal of Food Protection, 40: 843847.

Trout, E. S., Hunt, M. C., Johnon, D.E., Claus, J. R., Kastner, C. L., Kropf, D. H., and Stroda, S.1992. Chemical, physical and sensory characterization of ground beef containing 5 to 30 percent
fat.Journal of Food Science, 57: 25-29. Witte, V. C., Krause, S. F., and Baily, M. E.1970.A new extraction method for determining 2 thiobarbituric acid values of pork and beef during storage.Journal of Food Science, 35, 582-585.

Yadav, S., Tiwari, D., andUpadhyay, S.2019. Chemical Analysis of Herbal Paneer. International Journal of Recent Advances in Multidisciplinary Research. (06) 05,4911-4915

\section{How to cite this article:}

Saurabh Karunamay, Shekhar R. Badhe, Vivek Shulka, Poonam A. Pawar. 2020. Effect of Edible Packaging Film Treated with Essential Oil of Oregano in Extending the Shelf Life of Paneer. Int.J.Curr.Microbiol.App.Sci. 9(06): 2234-2242.

doi: https://doi.org/10.20546/ijcmas.2020.906.273 